Relations industrielles

Industrial Relations

\title{
William Kaplan, Jeffrey Sack and Morley Gunderson, eds. Labour Arbitration Yearbook
}

\section{Donald Carter}

Volume 47, numéro 2, 1992

URI : https://id.erudit.org/iderudit/050776ar

DOI : https://doi.org/10.7202/050776ar

Aller au sommaire du numéro

\section{Éditeur(s)}

Département des relations industrielles de l'Université Laval

\section{ISSN}

0034-379X (imprimé)

1703-8138 (numérique)

Découvrir la revue

Citer ce compte rendu

Carter, D. (1992). Compte rendu de [William Kaplan, Jeffrey Sack and Morley Gunderson, eds. Labour Arbitration Yearbook]. Relations industrielles / Industrial Relations, 47(2), 374-375. https://doi.org/10.7202/050776ar

Tous droits réservés (C Département des relations industrielles de l'Université Laval, 1992
Ce document est protégé par la loi sur le droit d'auteur. L'utilisation des services d’Érudit (y compris la reproduction) est assujettie à sa politique d'utilisation que vous pouvez consulter en ligne.

https://apropos.erudit.org/fr/usagers/politique-dutilisation/ 


\section{RECENSIONS BOOK REVIEWS}

Labour Arbitration Yearbook, edited by William Kaplan, Jeffrey Sack and Morley Gunderson, Toronto, Butterworths-Lancaster House, 1991, vol. 1, 283 p., ISBN 0-409-89867-8, vol. Il, 322 p., ISBN 0-409-89945-3

This two-volume work is the first instalment of an annual series designed to provide a forum for arbitrators, academics, and practitioners to discuss the current state of labour arbitration in Canada. The editors have succeeded in recruiting a distinguished group of contributors from Canada's arbitration community, and as well two respected academics from outside Canada, and it is their individual contributions that form the content of the yearbook. Included in the two volumes is a wide spectrum of topics affecting both grievance and interest arbitration, providing a good mix of both emerging developments and problems that have a more familiar look to them. This annual series is long overdue in Canada. Our conventional treatises on arbitration, while providing us with a comprehensive collection of the individual cases, have been singularly lacking in commentary and criticisms of the existing process. This series provides a more critical analysis of our established arbitral institutions and does so from a number of perspectives.

I was particularly impressed by those parts of the first two volumes where a single issue was viewed from an arbitrator's perspective, management's perspective, and the employee's perspective. Issues presented in this way included the right to privacy in employment; the employee's duty to "work now. grieve later"; arbitral treatment of criminal and immoral acts; whistleblowing; and the concept of ability to pay in the public sector. A somewhat similar approach was taken for the topic of gender issues in arbitration where this development was viewed from an academic perspective, a management perspective, and an employee's perspective. This approach, which analyses a single issue from at least three perspectives, was most effective and I hope that we will see much more of it in future volumes.

A majority of topics, however, were viewed only from a single perspective. This group of topics included expedited arbitration, bias, the Canadian Railway Office of Arbitration, grievance arbitration in the United States, alcoholism and drug dependency, the rights of disabled workers at arbitration, first contract arbitration, the duty of fair representation, discharges and reinstatements, unjust dismissal under federal jurisdiction, judicial review, strike-related misconduct, gender effects at arbitration, and an analysis of the present state of the grievance arbitration process. It appears as though the editors left no stone unturned in their selection of topics.

This latter collection of discrete topics did have its weaknesses. While I found these essays to contain some interesting insights, greater depth might 
have been provided if these issues had been viewed from more than one perspective. Perhaps for future volumes the editors might consider including fewer topics, but have each of these topics covered more fully. Another flaw is that the breadth of coverage made it difficult for the reader to discern any overall themes that might tie together these disparate contributions, since the editors have provided us with only a very brief preface to each of the two volumes. What is needed instead is a much fuller introduction where the editors create some order from what is otherwise a grab bag of discrete topics.

These minor flaws, however, do not overshadow what is an important contribution to Canada's industrial relations literature. What is most impressive about these two volumes is the extent to which the editors have succeeded in promoting a critical analysis of labour arbitration in Canada. This series should be high on the reading list of all those who have an interest in this important labour relations institution.

Donald CARTER

Queen's University

Labour Arbitration Yearbook, sous la direction de William Kaplan, Jeffrey Sack et Morley Gunderson, Toronto, Butterworths-Lancaster House, 1991, vol. 1, 283 p., ISBN 0-409-89867-8, vol. II, 322 p., ISBN 0-409-89945-3

Sous une couverture "annuelle", ces trois éditeurs y regroupent près de 20 articles portant sur les grandes questions relatives à l'arbitrage au Canada. La présentation des textes semble répondre d'un même plan:

1) Les questions de fond relatives à l'arbitrage des griefs (environ 5 articles);

II) L'actualité ou les débats de l'heure (5 thèmes);

III) L'arbitrage des différends ( 3 articles).

Chacun des deux premiers volumes de cette nouvelle collection débute de la même manière: une courte préface présente les thèmes qui y sont développés, une note biographique des auteurs (une vingtaine de personnes) et un hommage à une personne marquante en ce milieu des relations du travail. Le premier de ces témoignages fut rendu à monsieur Jacob Finkelman et le deuxième, à Me Marc Lapointe.

Les thèmes développés aux parties II et III comprennent, outre le développement principal, la version ou le commentaire de représentants des milieux syndicaux et patronaux. Ces articles ou commentaires ont respectivement 15 à 20 pages ce qui, bien évidemment, permet une lecture facilement accessible. De plus, chaque texte est précédé d'un résumé succinct, une sorte d'invitation à la lecture. Ainsi construit, chaque volume prend un peu la facture propre à un rapport d'un colloque.

Parce que nous ne pouvons, en ce cadre, rendre compte de chacun des trente articles de ces volumes I et II de cette nouvelle parution, nous nous 